\title{
Relasi Kelisanan Al-Qur'an dan Pancasila Dalam Upaya Menjaga dan Mengembangkan Identitas Islam Indonesia
}

\author{
Muhammad Alwi HS \\ Universitas Islam Negeri Sunan Kalijaga Yogyakarta \\ Email:muhalwihs2@gmail.com \\ Nur Hamid \\ Universitas Islam Negeri Walisongo Semarang \\ Email: elnur.hamid@walisongo.ac.id
}

\begin{abstract}
Yudian Wahyudi voiced his idea that Indonesia (read: Pancasila) is a religious and secular country simultaneously. The idea arose because many said Indonesia was a secular country, on the other hand, it was also mentioned that Indonesia was a religious country. It is said as a secular country because Indonesia has a lot of 'oriented' to the West. While referred to as a religious country becauseit has the majority Muslim population in the world. This paper will explain the position of the Pancasila as the way of life of the Indonesian people, associated with the Qur'an which is a way of life for Muslims. In this context, at Qur'an will be explained as the realm of its orality, as is the identity of the Qur'an delivered verbally: from Allah, the Angel Gabriel, the Prophet Muhammad to the Arab community (audience). In this case, reading the oral side of the Koran, through the theory of Orality from Walter J. Ong will be important if it is realized that there are distinct characteristics for oral delivery, one of which is the context that was born in the oral demands of the present, that is, when the Qur'an is delivered verbally, then the solution-problem or message delivered is based on the current context. At this point, Pancasila is present on Indonesian soil to answer problems and give messages that are also based on the Indonesian context Also, through the integration of general knowledge in understanding and applying the values of Pancasila and the beauty of the Qur'an, it will give birth to a national and religious attitude that always responds to the development of the times appropriately. Both of theselife guidelines maintain Indonesia's existingidentity-whichisgood and advance the life of the nation and state.
\end{abstract}

Keywords: Kelisanan al-Qur'an, Pancasila, Islam, dan Indonesia.

\begin{abstract}
Abstrak
Yudian Wahyudi kembali menyuarakan gagasannya bahwa Indonesia (baca: pancasila) adalah negara yang religius sekaligus sekuler secara bersamaan. Gagasan tersebut muncul karena banyak menyebut Indonesia adalah negara sekuler, di sisi lainnya juga disebut bahwa Indonesia adalah
\end{abstract}


negara religius. Dikatakan sebagai negara sekuler disebabkan Indonesia banyak 'berkiblat’ ke Barat. Sementara disebutsebagainegara religius karena memilikimayoritas pendudukMuslim terbesar di dunia. Tulisan ini akan menjelaskan posisi pancasila sebagai pandangan hidup masyarakat Indonesia, dikaitkan dengan al-Qur'an yang merupakan pedoman hidup umat Islam. Dalam konteks ini, al-Quran akan dijelaskan sebagai ranah kelisanannya, sebagaimana jati diri al-Qur'an yang disampaikan secara lisan: dari Allah, Malaikat Jibril, Nabi Muhammad kepada masyarakat Arab (audiens). Dalam hal ini, pembacaan sisi kelisanan al-Qur'an, melalui teori Orality dari Walter J.Ong, akan menjadi penting dilakukan jika disadari adanya kekhasan tersendiri bagi penyampaian lisan, salah satunya adalah konteks yang lahir dalam lisan menuntutmasa kini, artinya, saat al-Qur'an disampaikan secara lisan, maka solusi-problem atau pesan yang disampaikan berdasarkan konteks saat itu. Pada titik ini, Pancasila hadir di bumi Indonesia untuk menjawab problem dan memberi pesan yang juga berdasarkan konteks Indonesia. Selain itu, melalui integrasi ilmu umum dalam memahami dan mengaplikasikan nilai-nilai pancasila dan kelisanan al-Quran, maka akan melahirkan sikap berbangsa dan beragama yang senantiasa merespons perkembangan zaman dengan tepat. Kedua pedoman hidup tersebut mempertahankan jati diri Indonesia yang telah ada yangbaik, danmemajukankehidupan berbangsa dan bernegara.

Kata Kunci: Kelisanan al-Qur'an, Pancasila, Islam, dan Indonesia.

\section{Pendahuluan}

Dalam beberapa kesempatan Yudian Wahyudi, Rektor UIN Sunan Kalijaga, terus menyuarakan gagasannya bahwa Indonesia (baca: pancasila) adalah negara yang religius sekaligus sekuler secara bersamaan. Sepintas lalu, pandangan Yudian Wahyudi ini berseberangan dengan pernyataan Soekarno, sebagai tokoh utama Pancasila, yang mengatakan bahwa Indonesia, dengan adanya Pancasila, bukan negara agama juga bukan negara sekuler (Hariyono 2014). Tetapi, pandangan Yudian tersebut akan segera dipahami jika mengetahui kegelisahan yang mengitarinya. Indonesia kerap kali disebut sebagai negara sekuler satu sisi, sementara di sisi yang lain juga disebut sebagai negara religius. Dikatakan sebagai negara sekuler disebabkan Indonesia banyak 'berkiblat' ke Barat. Sementara Indonesia disebut sebagai negara religius oleh karena memiliki mayoritas penduduk Muslim terbesar di dunia. Menanggapi berbagai pernyataan tersebut, Yudian menegaskan bahwa semua sila yang ada dalam pancasila merupakan bentuk religius sekaligus sekuler secara bersamaan. Hal ini dapat dibuktikan misalnya- pada sila Ketuhanan Yang Maha Esa merupakan semangat religius, sementara untuk membangun tempat Ibadah (Mesjid) merupakan bagian dari sekuler.

Penjelasan Yudian tersebut dapat dipahami bahwa Indonesia sebagai negara akan terus berproses dalam merespon perkembangan zaman. Dalam konteks ini pancasila tidak hanya menjadi hasil kesepakatan dari masa lalu, tetapi akan terus mengalami perkembangan dari setiap anak generasi. Namun demikian, dalam penerapannya pancasila tidak mendapat perhatian signifikan oleh kalangan tertentu, misalnya oleh kalangan Hizbut Tahrir Indonesia (HTI). Kelompok HTI, meskipun telah dibubarkan, ini tetap menganggap bahwa Pancasila dibuat oleh 
manusia, sehingga meragukan bagi kelompok tersebut untuk dapat dijadikan pedoman hidup, terlebih lagi mereka (HTI) menganggap bahwa ketaatan kepada Pancasila akan mengesampingkan hukum Tuhan. Pandangan tersebut telah banyak mendapat sanggahan dari berbagai kalangan di Indonesia, baik akademisi maupun ulama Indonesia.

Titik fokus perdebatan Pancasila di kalangan umat Islam selalu dikaitkan dengan al-Qur'an. Al-Qur'an yang bersumber langsung kepada Allah disebut-sebut sebagai hukum Allah, sementara Pancasila karena lahir dari tangan manusia, maka ia bukan hukum Allah. Kita tidak sedang mempersoalkan apalagi hendak menolak bahwa al-Qur'an hari ini bersumber Nabi-jibril-Allah. Tetapi, yang menjadi fokus bahasan ini, adalah menyadari bahwa al-Qur'an yang ditemui adalah al-Qur'an yang sudah dalam bentuk mushaf (tulisan). Ini penting diungkapkan, sebab alQur'an pada era pewahyuan disampaikan secara lisan (verbal) yang memiliki karakter pemahaman tersendiri, yang berbeda ketika al-Qur'an sudah berada dalam bentuk mushaf. Ali bin Abi Tholib, misalnya, pernah berkomentar al-Qur'an ketika sudah berada dalam bentuk mushaf, ia mengatakan bahwa al-Qur'an tidak lagi memberi penjelasan kepada manusia, tetapi manusialah yang memberinya penjelasan, konsekuensinya adalah lahirnya ragam pemahaman atasnya (Misrawi 2017).

Kaitannya dengan Pancasila, persoalan kita pada dasarnya adalah cara pandang kita terhadap al-Qur'an dan Pancasila. Kita tidak hanya membedakan keduanya dari segi sumbernya, tetapi juga dalam proses memahami kehadirannya. Kerap kali kita mengabaikan pada apa yang menjadi spirit, nilai, petunjuk, dari kehadirannya. Kita lebih memandang Pancasila dan al-Qur'an dalam bentuk Mushaf sebagai 'kata benda' sehingga cenderung bersifat 'mati' tidak bersuara (Misrawi 2017). Tak berfungsi, dan memiliki nilai gerak. Pancasila hampir saja kehilangan nilai-nilainya, kita bisa mengambil contoh disini bahwa semua orang sepakat bahwa Keadilan Sosial bagi seluruh Rakyat Indonesia adala butir Pancasila yang sangat tepat dalam kehidupan berbangsa dan bernegara, akan tetapi kenyatannya masih sangat banyak orang-orang yang 'mengkhianati' pasal tersebut. Demikian juga al-Qur'an, semua orang sepakat bahwa al-Qur'an melarang radikalisme, kekerasan, sebaliknya alQur'an memerintahkan untuk bersikap damai, toleran. Tetapi kenyatannya masih sangat banyak umat Islam malah melakukan radikalisme, kekerasan, sebaliknya, umat Islam seakan menghindari perdamaian, toleran, dan sebagainya.

Selama al-Qur'an dibiarkan berada dalam kungkungan tulisan yang 'diam' maka selama itu pula al-Qur'an tidak akan menyentuh perkembangan zaman manusia, apalagi untuk bisa dikaitkan dengan Pancasila. Maka dari itu, kita harus 'kembali ke Al-Qur'an', yakni al-Qur'an yang disampaikan pada era pewahyuan, alQur'an dengan karakteristik pemahamannya berdasarkan kelisanan (verbal). Dengan demikian, kita akan dapat berbicara lebih jauh tentang nilai-nilai, 
pedoman, dan spirit al-Qur'an. Dari sini, kita juga akan dapat menemui titik temu hubungan al-Qur'an dengan Pancasila, serta bagaimana al-Qur'an dan Pancasila dapat didialogkan dengan perkembangan zaman. Melalui pemahaman al-Qur'an versi karakter kelisanannya akan terlihat bagaimana al-Qur'an berdialog dengan masyarakat Arab, serta bagaimana al-Qur'an berdialog dengan masyarakat Indonesia, dalam hal ini ulama modern menyebutnya kontekstualisasi, di sini penulis menyebutnya sebagai Verbalisasi.

Perlu penulis sampaikan bahwa dalam tulisan, kita tidak akan membahas panjang lebar tentang Pancasila: sejarah, sila-sila, dan sebagainya, hal ini karena sebagai sebuah istilah, Pancasila bukan barang baru bagi masyarakat Indonesia. Diskusi Pancasila hanya akan difokuskan pada pembahasan-pembahasan yang bersifat subtansi, yang penting diutarakan dan dipahami (kembali). Sebaliknya, kita akan berpanjang-lebar terlebih dahulu membahas apa dan bagaimana itu kelisanan al-Qur'an yang dimaksud dalam tulisan ini. Dari sini, tulisan ini akan banyak 'membawa' al-Qur'an bukan tempat 'kelahirannya', tetapi dalam konteks yang jauh berbeda dengan Arab, konteks Indonesia: sebagai konteks kedua, konteks di mana banyak pembaca baru yang mengimaninya.

\section{Kembali Kepada Kelisanan Al-Qur'an}

Definisi Kelisanan al-Qur'an

Sudah menjadi pemhaman umum bahwa al-Qur'an adalah kalamullah. Dari segi bahasa, misalnya dalam kamus Lisan Arab, kata kalam bermakna ungkapan yang terbentuk dari suara yang memiliki kesempurnaan fungsi (Mandzur n.d.). Sementara dalam diskursus tata bahasa (nahwu) kata kalam didefini sikan sebagai huwa al-lafdz murakkab al-mufib, ungkapan yang terususn dan memiliki fungsi. Senada dengan definisi ini, Henry Sweet -sebagaimana dikutik Ong- menyatakan bahwa sebuah kata itu sendiri tidaklah ada karena adanya huruf, ataupun susunan huruf. Tetapi kata tercipta dari unit suara dengan menampilkan fungsinya (Ong 2013). Makna ini senada dengan pemahaman orality dalam kamus Oxford, yakni penyampaian komunikasi yang dilakukan secara lisan (verbal) (Great Clarendon Street 2019). Kata lisan dalam kamus Lisanun Arab bermakna penyampaian ujaran (kalam) ke dalam bentuk kata-kata (Mandzur n.d.). Dalam Kamus Besar Indonesia Kontemporer, kata lisan berarti tutur kata, perkataan, dan ucapan (Salim n.d.). Pada titik ini memberi pemahaman bahwa al-Qur'an sebagai kalamullah merupakan komponen kata yang tersusun dari suara yang memiliki fungsi. Lebih jauh, dalam diskusi ulumul Qur'an, Manna Al-Qaththan, demikian juga dengan 
ulama umumnya, memberi definisi al-Qur'an dengan berangkat dari asal katanya, yakni qara'ah, yang kemudian dipahaminya sebagai huruf-huruf atau kata-kata yang dirangkai sehingga menjadi sebuah ungkapan (Al-Qaththan 2005).

Dari tutur kata tersebut menjadikan bahasa lisan sebagai wujud dari Bahasa (Ullmann 2012), yang dalam prakteknya menghasilkan intonasi sebagai kekhasan dari bahasa lisan itu sendiri (Samsuri 1982). Karena itu, bahasa Lisan dapat dikatakan menempati posisi lebih awal dibandingkan dengan bahasa tulisan. Dilihat dari fungsinya, bahasa (lisan) berfungsi sebagai alat komunikasi yang di dalamnya menghendaki atau mengutamakan adanya kesepahaman antara penutur dan pendengar tuturan (audiens) (A. A. Hidayat 2009). Ditarik ke dalam proses penyampaian al-Qur'an secara lisan, dari Nabi Muhammad kepada umat manusia, maka dipahami bahwa tuturan yang disampaikan oleh Nabi Muhammad mendapat pemahaman atau saling memberi pemahaman kepada pendengar tuturannya, dalam hal ini masyarakat Arab.

\section{Landasan Kelisanan al-Qur'an: Al-Qur'an, Hadis, dan Fakta Sejarah}

Bagian ini akan memperlihatkan kelisanan al-Qur'an ketika dalam proses pewahyuan dari (Allah, malaikat jibri), Nabi Muhammad kepada Masyarakat Arab. isu tentang proses pewahyuan ini menjadi salah satu isu penting dalam sejarah al-Qur'an, ia bahkan menjadi pembahasan sentral di berbagai diskusi alQur'an, dari klasik-moder-kontemporer. Ibnu Khaldun, cendikiawan besar dalam sejarah Islam, mengatakan bahwa kerap kali Nabi mendengar bisikan kata-kata dari malaikat Jibril, yang dipahaminya dengan cepat, kurang dari sekejap. Menurutnya, kejadian ini hal yang wajar sebab makna dari wahyu sendiri adalah kecepatan (Khaldun 2000). Pada keadaan ini, menurut Muhammad Abdel Haleem, umat Islam memahami bahwa Nabi sedang mengalami 'komunikasi Qur'ani' dengan malaikat Jibril, pembawa Wahyu. Sementara itu, bagi orang-orang yang tidak memercayainya akan menganggap Nabi sedang kesurupan (Haleem 2001). Di tempat lain, Abdel haleem mengatakan bahwa keadaan yang seperti ini terjadi selama masa pewahyuan, secara bertahap-tahap dan sesuai dengan keadaan (Haleem 2004).

Dalam al-Qur'an kenyataan tentang kehadiran al-Qur'an sebagai teks lisan disebutkan beberapa kali oleh al-Qur'an sendiri, misalnya, al-Qur'an disebut sebagai Kalamullah yang didengar (QS. at-Taubah: 6), al-Qur'an sebagai Kalamullah yang dibacakan oleh Rasul yang buta huruf (QS. al-Jumu'ah: 2), dan 
lain sebagainya. Dalam hadis, pewahyuan al-Qur'an sebagai fenomena teks lisan terlihat sejak proses turunnya wahyu pertama di gua hira, di sana diceritakan bahwa Jibril menyampaikan Wahyu dengan perkataaan (berbicara) kepada Nabi Muhammad. Pada hadis lainnya, dijelaskan bahwa salah satu proses pewahyuan adalah ketika Malaikat (Jibril) mengubah diri menjadi manusia kemudian berkatakata dengan Nabi Muhammad, serta penjelasan dari hadis lainnya yang menggambarkan proses pewahyuan yang terjadi secara lisan. Fenomena kelisanan al-Qur'an ini tidak hanya ditemui dalam penyampaiannya dari Allah, Malaikat kepada Nabi Muhammad, tetapi penyampaian lisan yang paling nyata, yang dapat dijumpai dalam kesejarahan al-Qur'an, adalah penyampaiannya dari Nabi kepada masyarakat Arab.

Proses pewahyuan ini mengundang perdebatan antara dua kelompok besar dalam sejarah Islam, kelompok Mu'tazilah dan Asy'ariyah: Apakah al-Qur'an makhluk atau bukan (Sultan 1986). Pendapat Mu'tazilah dan Asy-ariyah dapat disatukan, yakni al-Qur'an yang dimaksud Asy-ariyah sebagai bukan makhluk adalah al-Qur'an yang berada di lauhil Mahfudz, sedangkan al-Qur'an yang makhluk, sebagaimana pendapat Mu'tazilah, adalah al-Qur'an yang ditemui dalam bentuk bahasa (Arab)(Wijaya 2009). Ingrid Mittson (2013), yang juga merespon perdebatan ini, mengatakan bahwa betapapun perdebatan teologis tersebut, umat Islam -siapapun dan dari kelompok manapun- meyakini bahwa al-Qur'an adalah kalamullah yang menempati kedudukan penting dan unik dalam kehidupannya.

Pembahasan dalam proses pewahyuan, mengutip pandangan Hasan Hanafi yang kemudian didukung oleh Yudian Wahyudi, baik Malaikat Jibril maupun Nabi Muhammad keduanya bersifat passive. Hasan Hanafi menegaskan bahwa Nabi Muhammad hanya bertugas menyampaikan, ia tidak mempunyai kepentingan dan memang hanya sebagai perantara (rasul) dalam menyampaikan wahyu (Hanafi 2003). Sehingga Malaikat Jibril dan Nabi Muhammad menyampaikan wahyu apa adanya. Dengan demikian, gelar al-amin (terpercaya) malaikat Jibril dan nabi Muhammad tidak ternodai (Wahyudi 2009). Pandangan ke-passiveר-an penyampai wahyu ini penting diutarakan, karena erat kaitannya dengan pesan Ilahi, termasuk bahasa Arab yang digunakan sebagai bahasa pewahyuan (QS. Thaha: 113, asy-Syuara: 195, Yusuf: 2, az-Zumar: 28, Fushshilat: 3, asy-Syura: 7, alZukhruf: 3, dan al-Ahqaf: 12). Imam Asy-Syafi'i, dalam bantahannya kepada pandangan bahwa al-Qur'an juga menggunakan bahasa lain selain bahasa Arab, 
mengatakan bahwa adanya kata yang digunakan dalam pewahyuan yang mirip dengan kata dari bahasa lain merupakan hal yang wajar dalam fenomena bahasa (Asy-Syafii 1992).

M. Quraish Shihab cenderung bersikap hati-hati dalam menentukan bahasa yang digunakan Allah, menurutnya hakikat al-Qur'an tidak diketahui oleh manusia, sebab kalam-Nya adalah sifat dzat-Nya yang sudah barang tentu diluar jangkauan manusia, bahkan seluruh makhluk-Nya. Beruntung kalamullah ini disampaikan dalam bahasa manusia, yakni bahasa Arab, sehingga manusia dapat memahami kandungannya (Shihab 2013). Senada dengan ini, Ziauddin Sardar berpandangan bahwa pewahyuan dari Allah, Jibiril, ke Nabi Muhammad tetap menjadi misteri Ilahi, ia adalah fenomena spiritual sehingga tidak mungkin dinalar oleh akal manusia (Sardar 2011). Nazaruddin Umar bersikap lebih berani dalam hal ini, ia mengatakan bahwa al-Qur'an yang berbahasa Arab adalah langsung dari Allah, inilah, menurutnya, yang juga menjadikan kalamullah memiliki unsur I'jaz (mukjizat) (Umar 2008). Aspek i’jaz ini kemudian, menurut Arkoun, kelak mengantar manusia mengungkap kandungan (risalah) dalam kitab suci ini (Arkoun 1998). Pada titik ini, menurut Kamaruddin Hidayat (K. Hidayat 2004), Izutsu (Izutsu 1997), dan Sugeng Suryono (Sugiyono 2009), bahwa al-Qur'an berada dalam bentuk bahasa Arab yang dalam pengungkapannya mengundang dan menggugah hati dan intelektual penerimanya, serta sebagai alat penyampai pesan Tuhan kepada manusia.

Sampai di sini, pada dasarnya peneliti hendak 'mengunci', minimal untuk memahami gerak penelitian ini, perdebatan proses pewahyuan dari Allah-Malaikat Jibril-Nabi Muhammad: tentang 'kemakhlukan' dan 'bahasa' al-Qur'an. Hal ini dengan catatan bahwa Allah-lah yang langsung merespon keadaan si 'objek' wahyu. Selanjutnya, setelah menerima wahyu, kutip Abdullah Saeed, Nabi Muhammad kemudian menuturkan wahyu yang diterimanya kepada masyarakat Arab (audiens), di sinilah wahyu menempati ruang kemanusiaan (Saeed 2016). Senada dengan Abdullah Saeed, para sarjana modern nampaknya telah mulai menyoroti kelisanan al-Qur'an sebagai fakta kesejarahan yang tak boleh diabaikan. Fadzlu Rahman (Rahman 2017), Nasr Hamid Abu Zaid (Nashr Hamid Abu Zaid 2002), dan lainnya mulai menampillkan pentingnya mengungkap al-Qur'an dari kelisanannya. 
Kenyataan yang juga tidak bisa diabaikan adalah keyakinan umat Islam mengenai al-Qur'an yang ada dihadapannya saat ini merupakan kalamullah yang mutawatir: disampaikan sesuai apa adanya dari Allah-Malaikat-Nabi hingga dalam bentuk mushaf. Jika demikian, maka dapat dipahami bahwa al-Qur'an yang ada dalam bentuk mushaf saat ini adalah teks lisan, dengan kata lain al-Qur'an dalam bentuk tulisan mengandung karakteristik kelisanan. Lebih jauh, fakta teks lisan ini dapat diperkuat melalui keadaan transmisinya menjadi mushaf, yang dalam hal ini transmisinya dilakukan secara lisan. Schoeler dengan berbagai data pra dan masa Islam dengan didampingi oleh argumentasi yang dibangunnya telah membuktikan bahwa transmisi pengetahuan Islam awal adalah transmisi lisan (Schoeler 2006), pandangan ini juga dipegang oleh pegiat sejarah Arab, seperti Philip K. Hitti (Hitti 2006).

\section{Urgensi Pemahaman al-Qur'an Berbasis Kelisanan}

Pembacaan sisi kelisanan al-Qur'an akan menjadi penting dilakukan jika disadari adanya kekhasan tersendiri yang dihasilkan oleh penyampaian secara lisan dibandingkan dengan penyampaian secara tulisan. Dalam penelitian sebelumnya, Penafsiran M. Quraish Shihab tentang QS. al-Qalam dalam Tafsir Al-Mishbah: dari Teks ke Lisan (HS 2019), peneliti telah membuktikan adanya karakteristik dan pemahaman tersendiri yang terkandung ketika 'sesuatu' disampaikan secara lisan. Padahal, penelitian tersebut dilakukan kepada penafsir yang sama, serta berangkat dari kitab tafsir yang sama (Tafsir al-Misbah), akan tetapi, karena disampaikan dengan bentuk berbeda -lisan dan tulisan, maka penafsiran $\mathrm{M}$. Quraish Shihab menghasilkan karakteristik dan pemahaman tersendiri pula antara apa yang tercantum dalam bentuk tulisan dengan apa yang disampaikan secara lisan.

Untuk memberi pemahaman atas perbedaan yang dimaksud, dapat dikemukakan contoh sederhana, misalnya kata kita berbeda makna ketika disampaikan dalam bentuk lisan dan tulisan, pada penyampaian lisan makna yang ditemui adalah satu, sesuai konteks audiens yang dihadapi. Sedangkan ketika kata kita ada dalam bentuk tulisan, maka ia akan melahirkan ragam makna -karena open publik. Karena itu, kata kita yang disampaikan secara lisan dalam konteks Makassar, Ternate, dan Indonesia menghasilkan makna yang berbeda: bagi konteks Makassar bermakna kamu, konteks Ternate bermakna Aku, sedangkan konteks Indonesia bermakna aku dan kamu. 
Dalam konteks al-Qur'an, di sini dapat diambil contoh tentang kata ahlun (Baqi 1984) dalam kamus klasik seperti Lisanun Arab dan Mu'jam Maqayis Lugah bermakna pemilik (Zakariya 1979). Akan tetapi dalam QS. an-Nisa: 58, innallah ya'murukum an tuaddu amanatikum ila ahliha, makna ahlun tersebut tidak diketahui. Secara sintagmatik, kata ahlun bersanding dengan kata amanah, sebagaimana dhamir Ha yang kembali kepada kata amanatun. Pada titik ini, untuk membantu mengetahui rujukan kata ahun tersebut, maka perlu ditampilkan asbabun nuzul-nya. Ayat ini turun berkaitan dengan pemegangan kunci Ka'bah yang menjadi wewenang Usman bin Thalhah (Asy-Syuthi 2008). Yang menarik dalam dialektika ayat dan konteksnya ini adalah meski ayat ini tidak menyebut langsung nama Usman bin Thalhah, akan tetapi ketika ayat ini turun: diperintahkan untuk memberikan amanah kepada ahlinya, Nabi langsung menyerahkan kunci Ka'bah yang telah direbutnya, kepada Usman bin Thalhah. Dari sini dapat dipahami bahwa kata ahlun memberi makna temporal (saat itu), yang dalam hal ini merujuk kapada Usman bin Thalhah (Abbas 2004).

Inilah yang terjadi oleh perbedaan lisan dan tulisan, bahwa terjadi keberadaan konteks yang ikut berpengaruh pada pemahaman atas al-Qur'an. Konteks yang lahir dalam lisan menuntut masa kini, yakni ruang konteks yang sama antara penutur dan pendengar tuturan. Sementara konteks dalam tulisan menciptakan jarak dan tempat yang berbeda antara penulis dan pembaca (Ong 2013). Lebih jauh, konteks dalam kelisanan menjadikan kelisanan bertindak sebagai kesaksian. Kesaksian ini mengikuti konteks dari penutur dan pendengar bahasa (Vansina 2014). Sebaliknya, bahasa tulisan hanya dapat menjadi saksi, tetapi tak dapat menjadi kesaksian (Vansina 2014). Hal ini karena tulisan tidak memiliki konteks yang jelas atau biasa dikenal sebagai bebas konteks (Ong 2013). Tidak jelasnya konteks dalam tulisan menjadikannya lebih sulit dipahami dibanding penyajian lisan, bahkan akibatnya dapat menyebabkan makna yang dimaksud tulisan bersifat kabur (Saussure 1988). Muhammad Abduh, dalam satu kesempatan, mengatakan bahwa penyampaian secara lisan lebih mudah dipahami, delapan puluh persen, daripada karya tulis (Shihab 1994).

\section{Dialog Kelisanan al-Qur'an dengan Konteks Indonesia}

Berkenaan dengan jati diri al-Qur'an ini sebagai teks lisan, maka al-Qur'an mestinya dikaji dalam konteks kelisanan. Sebagaimana dijelaskan sebelumnya, 
bahwa terdapat perbedaan yang signifikan tentang konteks dalam ranah bahasa lisan dengan bahasa tulisan. Konteks yang dihasilkan oleh bahasa lisan bersifat konkrit, jelas, artinya konteks dapat diketahui saat itu juga. Sementara konteks yang dihasilkan oleh bahasa tulisan bersifat abstrak atau bebas konteks, yakni sebuah tulisan terlepas dari konteks penulis dengan pembaca teks. Dari sini muncul jarak antara penulis dengan pembaca, khususnya mengenai konteks (Nasr Hamid Abu Zaid 2003). Oleh karena itu, penulis berpendapat bahwa umat Islam sedang butuh pelepasan diri dari pemahaman tekstualitas al-Qur'an, hal ini karena seringkali ditemukan pemahaman yang tak bisa membedakan antara spirit, nilai dan ajaran Islam yang terkandungan dalam al-Qur'an, dengan teks tulis al-Qur'an sendri yang melibatkan budaya Arab di dalamnya. Sehingga terjadi simpang siur antara Islam, budaya Arab, dan budaya Indonesia.

Umat Islam, dan sebagaimana juga disebut oleh al-Qur'an sendiri bahwa alQur'an menjadi pedoman hidup (QS. al-Baqarah: 02, 158), membebaskan diri dari penindasan menuju kesetaraan, memberi pencerahan dalam setiap sudut masalah kehidupan, menenangkan jiwa yang gelisah, serta mengarahkan manusia menjadi manusia yang bahagia dunia dan akhirat. Semua orang dari seluruh belahan tentu sangat menginginkan kehidupan yang bahagia tersebut, tidak ada satupun yang ingin terus berada pada kesengsaraan hidup. Karena itu, manusia khususnya umat Islam- percaya dan yakin bahwa al-Qur'an dapat membimbing mereka. Berislam berarti menjadikan diri ini memahami ajaran agama dengan baik, yang kemudian diamalkannya ke aktivitas sehari-hari. Dari sini, kemudian melahirkan pribadi yang mulia, yang kemudian berkembang menjadi masyarakat islami. Demikian yang menjadi perjalanan hidup masyarakat Arab. Melalui teladan yang diperlihatkan serta diajarkan, Nabi berhasil mengubah masyarakat yang ditemuinya dari kejahiliyan menjadi masyarakat yang bermartabat, shaleh, dan banyak istimewa-istimewa lainnya.

Dari perjumpaan masyarakat Arab dengan ajaran Islam tersebut, perlu menjadi catatan penting bahwa upaya-upaya yang dilakukan Nabi selama masa penyebaran ajaran Islam terjadi beriringan dengan keadaan konteks yang dihadapinya. Sehingga setiap wahyu (baca: al-Qur'an) senantiasa saling merespons atau berdialog oleh keadaan disekitar Nabi (As-Shali 1993). Karena itu, melihat konteks kehidupan Nabi, konteks masyarakat Arab secara umum (Qadafy 2015), serta konteks masyarakat Indonesia perlu disadari dan dipahami, agar dapat 
menemukan spirit atau pesan yang selama ini menjadi titik fokus usaha Nabi Muhammad SAW.

Ada banyak orang yang berharap dapat meneladani ajaran yang dilakukan oleh $\mathrm{Nabi}$, tetapi karena mereka mengabaikan konteks kehidupan Nabi, sehingga mereka pada akhirnya terperangkap pada keterbukaan makna teks agama. Mereka memahami ajaran Nabi dengan mengikuti apa yang hanya termuat pada tulisan, hingga mereka akhirnya bersikap sesuai tulisan, jauh dari yang semestinya terjadi oleh diri Nabi beserta konteks yang dihadapinya. Terlebih lagi, mereka lupa bahwa situasi konteks satu tempat dengan tempat lainnya saling berbeda. Arab yang nun jauh dari Indonesia, sudah tentu mengalami banyak perbedaan. Masyarakat Arab yang memiliki gaya hidup, aturan sosial sendiri, juga berbeda dengan masyarakat Indonesia, dan seterusnya. Singkatnya, setiap daerah memiliki keadaan tersendiri, karena itu setiap cara yang digunakan dalam merespons masalah sangat mungkin untuk berbeda.

Arab menjadi daerah sesuai dirinya, ia memiliki kekhasan tersendiri, baik sebelum dipertemukan dengan Islam maupun setelahnya. Demikian pula dengan Indonesia, ia telah memiliki budaya dan kekhasan tersendiri sebelum Islam menghampirinya. Sehingga tidak tepat sekaligus tidak benar jika jati diri -budaya dan sebagainya- Indoneia yang secara kesepakatan umum dianggap baik itu ditinggalkan, kemudian mencampur adukkan Indonesia Arab. Ketika Islam dihadapkan dengan budaya Arab, Nabi Muhammad menyadari pentingnya pemanfaatan perantara dalam penyebaran ajaran agama. Dari sini budaya Arab itu diambil, dibangun, berkembang, dan kemudian dipertahankan. Menjaga budaya adalah menjaga jadi diri manusia itu sendiri, mengabaikannya hanya akan menyiksa manusia. Saking pentingnya menjaga budaya tersebut, Haidar Bagir mengemukakan bahwa "Budaya adalah soal menjadi manusia (Bagir 2017)." Karena itu, menjadi bid'ah jika budaya Arab diterapkan di Indonesia, dan budaya Indonesia diterapkan di Arab. Masyarakat Arab menjadi Islam dengan budayanya, dan mempertahankan budayanya (tradisional) sampai saat ini adalah hal keharusan bagi mereka. Demikian juga Indonesia, yang berislam sesuai budaya mereka, yang harus dipertahankan.

Ketika orang pulau -yang biasanya menggunakan kendaraan kapal- hendak melakukan perjalanan keliling sembari menikmati kota, maka kendaraan kapalnya cukup sampai di pelabuhan saja, sebab kapal tidak dapat digunakan keliling kota, 
yang tepat adalah menggunakan kendaraan darat -misalnya mobil, motor, bus, dan sebagainya. Ia harus paham kapan dan di mana kapal itu digunakan, dan tidak boleh digunakan. Inilah yang disebut kontekstualisasi. Demikian pula ketika ajaran Islam hendak diterapkan di Indonesia, umat Islam dituntut untuk mampu mendialogkan ajaran Islam dengan konteks Indonesia.

Karena itu, pembacaan ajaran Islam dengan kontekstualisasi menjadi keharusan untuk selalu diterapkan. Ajaran Islam diserap melalui cara (metode) yang sesuai kebutuhan kehidupan di Indonesia. Upaya pencarian pesan-pesan ilahi harus terus dilakukan, yang kemudian dilanjutkan pada penerapan dalam konteks Indonesia. Hal inilah yang pada dasarnya telah dilakukan oleh para penyebar Islam awal di Indonesia, yang dikenal sebagai Walisongo. Para menyebar ajaran Islam tersebut senantiasa mendialogkan ajaran Islam dengan budaya lokal yang dijumpainya, sehingga Islam yang lahir adalah Islam yang berdialog, damai, dan ramah kepada masyarakat yang dijumpainya. Para walisongo tersebut sangat tahu dan dapat membedakan mana yang menjadi ajaran Islam yang disebarkan Nabi Muhammad, dan mana konteks kehidupan Nabi Muhammad di Arab.

Oleh karena itu, kiranya tepat yang dikemukakan Faisal Ismail menegaskan bahwa:

"Islam tidak sama dengan Arab. Islam tidak identik dengan kebudayaan Arab, Islam tidak identik dengan paham ke-Arab-an atau Arabisme. Arab atau Arabisme juga tidak identik dengan Islam (Ismail 2016)".

Upaya melakukan kontekstualisasi al-Qur'an ke Indonesia pada dasarnya telah banyak dilakukan oleh umat Islam, kita bisa mengambil contoh dari organisasi Nahdlatul Ulama dengan model Islam Nusantara-nya sebagai upaya mengkontekstualisasikan ajaran Islam di bumi Indonesia. Afifuddin Muhajir, sebagaimana dikutip dalam prolog Akhmad Sahal, menyatakan bahwa ajaran Islam yang disebarkan oleh Wali Songo dan ulama ahlussunnah wal jama'ah di Indonesia adalah "paham dan praktik keislaman di bumi Nusantara sebagai hasil dialektika antara teks syariat dengan realitas dan budaya setempat", dari sini dapat dipahami bahwa konsep Islam Nusantara pada dasarnya telah ada sejak awal penyebaran Islam itu sendiri, artinya eksistensi Islam Nusantara bukan sesuatu yang baru (Sahal and Aziz 2016). Lebih jauh, Abdurrahman Wahid, dengan ide "pribumisasi Islam" menyatakan bahwa (Wahid 2007): 
"Pribumisasi Islam "tidaklah mengubah Islam, melainkan hanya mengubah manifestasi dari kehidupan agama Islam". Selain itu, "pribumisasi Islam" tidak lantas menempatkan Islam dalam subordinatif budaya dan tradisi, tidak pula melakukan "jawanisasi" atau sinkretisme. Tujuannya adalah bagaimana agar Islam "dipahami dengan mempertimbangkan faktor-faktor kontekstual, termasuk kesadaran hukum dan rasa keadilannya," dan bagaimana agar kebutuhan-kebutuhan lokal dipertimbangkan dalam merumuskan hukum agama, tanpa mengubah hukum itu sendiri".

\section{Pertemuan Kelisanan al-Qur'an dan Pancasila}

Sebelumnya telah dijelaskan bahwa Arab dan Indonesia memiliki ciri khas tersendiri yang menjadikan dua negara ini berbeda. Arab berkembang sebagaimana dirinya, demikian juga Indonesia yang berkembang sebagaimana apa yang ada dalamnbuminya. Pancasila hadir ditengah-tengah kemajemukan Indonesia, hingga terbangunlah masyarakat yang Bhinneka Tunggal Ika. Pancasila bukan hanya sebagai gagasan cemerlang dari sosok Soekarno, melainkan juga menjadi pedoman hidup masyarakat Indonesia. Karena pancasila sehingga sampai hari ini Indonesia masih menjaga keragamaannya, masih bersatu dalam jutaan perbedaan. Pancasila telah menjadi pedoman hidup masyarakat Indonesia. Hal ini senada dengan yang ditulis oleh Hatta, bahwa (Hatta 1977):

"Pancasila adalah dasar filsafat dari negara kita, negara Republik Indonesia. Dari sanalah terletak landasan-landasan politik, ekonomi, sosial, budaya dan segala sikap hidup dari bangsa Indonesia (tentu saja mereka yang meyakini makna Pancasila sebagai pandangan hidup, atau falsafah hidup bangsa Indonesia".

Pada titik ini, Pancasila memiliki relasi yang erat dengan kedudukan al-Qur'an dalam konteks menjadi pedoman hidup. Jika Al-Qur'an -sebagaimana dijelaskan sebelumnya- diyakini sebagai pedoman hidup, umat Islam dan Non-Islam (QS. alBaqarah: 02-158), maka Pancasila adalah pedoman hidup atas kemajemukan masyarakat Indonesia. Pedoman hidup itu tidak hanya untuk satu golongan saja, bukan hanya untuk umat Islam, tetapi untuk semua golongan, dari berbagai kalangan. Lebih jauh, al-Qur'an dan Pancasila hadir sebagai solusi berbagai permasalahan hidup manusia. Arab, sebagai tempat pertama kali diturunkan alQur'an, telah berhasil dibimbing, diubah, dan diperbaiki. Demikian juga kehadiran 
awal Pancasila yang telah mempersatukan kelompok Islamisme dan Nasionalisme, kala itu.

Solusi tersebut dapat dilihat bagaimana al-Qur'an mentransformasi, kita bisa mengambil contoh, tentang kehidupan perempuan sebelum dan setelah turunnya al-Qur'an. Sebelum al-Qur'an, kelahiran anak perempuan menjadi kecacatan keluarga. Tidak dinilainya derajat perempuan, bahkan seringkali terjadi penguburan hidup-hidup atas anak perempuan dan masih banyak perlakuan buruk terhadap kaum perempuan, antara lain tidak diberi hak waris dan hak-hak lain yang pada umumnya dinikmati oleh kaum lelaki (Al-Husaini 2000). Perlahan berbagai persoalan perempuan direspons secara transformasi oleh al-Qur'an. Pengangkatan derajat perempuan dilakukan oleh al-Qur'an, diberinya hak waris (lihat QS. anNisa ayat 11, 12, dan 176), dihargainya pendapat yang dikemukakannya (lihat QS. al-Mujadalah: 1), diperhitungkannya sebagai saksi (lihat QS. al-Baqarah: 282), bahkan Nabi dalam haditsnya secara tegas menjadikan perempuan sebagai partner laki-laki, "Sesungguhnya perempuan ialah partner laki-laki" (HR. Abu Dawud). Nasharuddin Baidan menjelaskan bahwa partner menunjukkan bahwa adanya saling ketergantungan satu sama lain, dalam hal ini laki-laki membutuhkan perempuan, dan sebaliknya (Baidan 1999).

Dalam konteks lainnya, gambaran transfomari yang melibatkan dalil agama dan Ijtihad sekaligus dapat dilihat pada inisiatif dikumandangkannya Adzan sebagai bentuk masuknya waktu shalat. Pada masa Nabi Muhammad, sebelum umat Islam banyak tersebar, shalat berjamaah dapat dilaksanakan dengan mudah. Akan tetapi seiring penyebaran Umat Islam, maka diadakanlah Adzan sebagai tanda masuknya waktu Shalat. Hal ini merupakan tindakan yang tepat seiring dalam merespon kebutuhan umat Islam saat itu. Lebih jauh, inisiatif adzan tersebut sebagai penyampaian masuknya waktu shalat ini kemudian berkembang dan dibantu oleh alat elektorik dalam bentuk Mikrofon, sehingga suara Adzan dapat menjangkau jarak yang lebih jauh. Tidak hanya itu, selain diadakan adzan dalam petanda masuknya waktu Shalat, bahkan dalam konteks saat ini audio mengaji dari elektronik juga telah dijadikan tanda masuknya waktu shalat.

Berkaitan dengan hal ini, Pancasila juga menjadi solusi atas permasalahan yang dihadapi oleh umat Islam di Indonesia, hal ini misalnya bagaimana masyarakat Indonesia yang tersebar di penjuru bumi Indonesia, dengan berbagai adat, bahasa, bahkan agama yang berbeda, dapat disatukan dalam sila Persatuan Indonesia. 
Sehingga melalui persatuan tersebut, masyarakat Indonesia dapat mengembangkan kualitas kehidupannya di lingkungan yang penuh perbedaan ini. Bentuk Persatuan Indonesia ini kemudian diabadikan dalam bentuk tanda bukti kewarganegaraan atau dikenal sebagai Kartu Tanda Penduduk (KTP) yang dengannya berbagai masyarakat dari berbagai perbedaan tersebut dapat memberi atau dan diberi hak yang sama di bumi Indonesia. Sehingga KTP tersebut adalah cara sekuler yang bertujuan mempersatukan hubungan antar masyarakat Indonesia (religius).

Berbagai solusi yang dihasilkan di atas, baik dalam konteks Pancasila maupun al-Qur'an merupakan upaya pencapaian pada nilai-nilai keagamaan (religius) dengan jalan pengaplikasian atas ijtihad-ijtihad dari berbagai disiplin pengetahuan. Artinya dalam menerapkan kandungan al-Qur'an, tidak cukup hanya ditinjau dari segi teologi semata, melainkan mesti ditinjau dari berbagai ilmu pengetahuan umum. Sama halnya dengan al-Qur'an, pancasila juga mesti dapat dipahami dari berbagai disiplin ilmu pengetahuan, sehingga nilai-nilai yang terkandung di dalamnya dapat selalu diterapkan. Demikian juga dengan Pancasila, ia perlu dipahami berdasarkan perkembangan ilmu pengetahuan. Dengan demikian, secara singkat agar al-Qur'an dan Pancasila dapat selalu relevan dengan keadaan umat Islam di Indonesia maka keduanya harus diintegrasikan dengan perkembangan keilmuan yang ada.

\section{Dialog Kelisanan al-Qur'an dan Pancasila dengan Perkembangan Zaman}

Pancasila sebagai pedoman hidup umat Islam di Indonesia, yang dalam hal ini bukan hanya boleh menggunakan disiplin ilmu pengetahuan lain (baca: Sains), akan tetapi memang semestinya memahami dan menerapkan kandungan alQur'an dan Pancasila dalam merespon perkembangan zaman, harus memakai berbagai disiplin ilmu pengetahuan. Dari sini Indonesia sebagai negara yang di dalamnya mayoritas umat Islam dapat digolongkan sebagai negara yang religius dan sekuler. Dalam arti bahwa religius karena meliputi umat beragama dari kalangan agama manapun, sementara dikatakan sekuler karena mengembangkan ilmu pengetahuan (sains). Pancasila sebagai dasar negara serta sebagai pedoman hidup masyarakat Indonesia, pancasila harus diintegrasikan dengan keilmuan lainnya. Sehingga pancasila tidak berhenti pada catatan sejarah semata, melainkan 
berdialog dengan perkembangan zaman. dalam konteks ini pancasila harus 'akrab' dengan perkembangan sains terlebih lagi ilmu matematika sebagai pusat segala keilmuan yang ada. Berkenaan dengan ini, kelisanan al-Qur'an sebagai solusi dalam kehidupan umat Islam (bahkan umat manusia secara umum) dapat terlihat dalam nilai-nilai Pancasila.

Ketuhanan yang Maha Esa (sila ke-1) merupakan dasar negara dan pedoman hidup yang paling Nampak nilai religiusnya, dengan sendirinya sila pertama ini menyebutkan dirinya agar masyarakat Indonesia dari berbagai agama apapun harus meyakini adanya Tuhan. Dari pasal pertama ini nilai kelisanan al-Qur'an yang tergambar adalah ketuhanan itu sendiri, yang memerintahkan manusia untuk beribada kepada Tuhannya (lihat an-Nisa:1). Tidak disebutkannya identitas Tuhan milik satu kaum dalam Pancasila tersebut menunjukkan bahwa masyarakat yang ditemuinya merupakan masyarakat dengan berbagai agama. Demikian juga dengan al-Qur'an yang menggunakan kata 'Tuhan' ketika berhadapan dengan manusia, itu artinya masyarakat yang ditemuinya tidak semua menganut satu agama semata.

Setelah meyakini adanya ketuhanan, dengan melalui agama sebagai jalan bertuhan, maka di sini peran ilmu pengetahuan (baca: Sains) agar diposisikan untuk menunjang keberlangsungan ibadah kepada Tuhan tersebut. melalui rumusrumus arsitek akan terbangun rumah ibadah yang nyaman digunakan dalam beribadah. Melalui ilmu lingkungan (biologi, fisika, kimia) akan mengelaborasi berbagai bahan alami menjadi bagian dalam pembangunan rumah ibadah tersebut. Bahkan dalam Islam tersendiri air tidak langsung dapat digunakan untuk wudhu, tetapi perlu label 'bersih dan suci' sehingga ia dapat digunakan. Standar untuk mengetahui bersih dan suci inilah yang melibatkan sains.

Kemanusiaan Yang Adil Dan Beradab (sila ke-2) dan Persatuan Indonesia (Sila ke-3) merupakan dua dasar negara sekaligus pedoman hidup masyarakat Indonesia yang tingkat religiusnya ditemukan dari penjagaan keharomisasian dalam berbangsa dan bernegara. Kedua sila tersebut menjunjung tinggi nilai moral, masyarakat Indonesia harus berperilaku adil dan beradab kepada siapapun, sehingga tercipta persatuan. Sikap adil dan beradab ini juga diperintahkan oleh alQur'an agar senantiasa berlaku adil dan beradab (lihat QS. al-Maidah:8). Selain itu, menjaga persatuan merupakan perintah sentral untuk mencapai keharmonisasian hidup, dalam konteks ini al-Qur'an menggunakan kata ta’aruf (QS.al-Hujurat:10) 
dalam membangun sikap atas perbedaan-perbedaan yang ditemukan dalam kehidupan ini. Kata ta'aruf yang digunakan oleh al-Qur'an tersebut menandakan adanya kemungkinan-kemungkinan (sensitif) konflik yang terjadi dalam perbedaan itu, sehingga perlu dihadapi dengan sikap tahu dan bijak dalam mengatasinya. Sikap bijak inilah akan melahirkan toleransi dalam berbangsa dan bernegara. Argumen tersebut akan nampak nilai religiusnya pada sila kedua dan ketiga tersebut. Terciptanya nilai religius dari sila kedua dan ketiga tersebut di atas tentu tidak lepas dari upaya sekuler di dalamnya. Penciptaan sikap adil dan beradab akan tercapai melalui sistem elektronik yang diciptakan dan diterapkan secara merata. Adanya KTP misalnya, akan melahirkan sikap kemanusiaan dan persatuan dalam berbagai urusan administari. Dalam pembuatan KTP ini senantiasa menggunakan Sains (ilmu pengetahuan) dengan berbagai rumus-rumusnya.

Kerakyatan yang dipimpin oleh hikmat kebijaksanaan dalam permusyawaratan perwakilan merupakan upaya pencapaian kehidupan bernegara dan berbangsa yang mengedepankan kemakmuran rakyat, sehingga sila ini mengikutkan kata kerakyatan dengan kebijaksanaan. Berkenaan dengan ini semangat kelisanan alQur'an adalah mengapresiasi kehidupan masyarakat yang baik. Hal ini tergambar dalam -misalnya- aturan Jilbab yang semula merupakan budaya Arab untuk membedakan budak perempuan dengan perempuan yang merdeka. Upaya 'kebaikan' rakyat ini akan terlihat dalam bentuk-bentuk kebijakan pemerintah yang berpihak kepada masyarakat yang dipimpinnya. Penyeleksian untuk menjadi perwakilan dalam konteks saat ini dikenal dengan demokrasi, yakni semua masyarakat Indonesia berhak memilih siapa yang hendak diwakilkannya dalam menentukan masa depannya di kanca pemerintah. Tentu dalam pemilihan tersebut diutamakan kepada orang-orang yang ahli-ahli dalam bidangnya, urusan agama diberikan kepada ahli agama, urusan kenegaraan diberikan kepada ahli kenegaraan. Sehingga dalam hal ini senada dengan perintah al-Qur'an dalam pemberian amanah kepada ahlinya (QS. an-Nisa: 58). Dengan demikian, nilai kerakyatan dari sikap amanah inilah yang menjadikan sila keempat tersebut bersifat religius. Konteks saat ini, semangat kerakyatan dalam sila keempat tersebut di atas dapat disaksikan bahkan diawasi dengan bantuan teknologi informasi. Kinerja perwakilan rakyat dengan saat yang sama dapat ketahui oleh masyarakatnya, sehingga amanah kerakyatan tersebut digunakan dengan sebaik-baiknya. Dari sini 
terlihat bagaimana perkembangan ilmu pengetahuan sangat membantu masyarakat dalam bernegara.

Keadilan sosial bagi seluruh rakyat Indonesia merupakan penutup sila-sila dalam pancasila yang menghadirkan keadilan sosial. Ini menandakan bahwa masyarakat Indonesia yang mencakup kalangan, golongan, dan agama yang berbeda-beda, yang harus diperlakukan seadil-adilnya. Dalam konteks ini siapapun dan dari manapun asal dirinya mengaku rakyat Indonesia, maka akan diperlakukan dengan adil. Sila kelima ini adalah puncak kemaslahatan dalam bernegara dan beragama di bumi Indonesia. Semangat keadilan sosial ini pula yang menjadi semangat transfomasi sosial dalam dakwah Nabi. Pemerdekaan budak-budak, pengangkatan hak dan martabat perempuan, bahkan kesamaan dalam kehidupan sosial -hanya keimanan yang membedakan. Kesemua ini menunjukkan adanya relasi keadilan sosial bagi seluruh rakyat yang tergambar dalam pancasila dan alQur'an.

Dalam pencapaian keadilan sosial tersebut mengundang berbagai keilmuan sehingga dapat dirasakan secara konkrit bagi masyarakat. Hal ini-misalnya-terlihat dengan adanya pembangunan jalan tol, bandara, pelabuhan di berbagai daerah sehingga semua masyarakat merasakan fasilitas yang sama. Berbagai pembangunan sarana masyarakat tersebut tentunya dirancang melalui kecanggihan sains dengan berpusat pada perhitungan (matematika) sehingga tercipta sarana yang membuat masyarakat terlayani secara adil.

Dari berbagai pemaparan tersebut di atas, menunjukkan keterikatan yang erat antara al-Qur'an, pancasila dan sains. Melalui kelisanan al-Qur'an, terlihat pancasila dapat eksis dihadapan umat Islam sebagai dasar negara yang religius. Melalui sains, pancasila dan al-Qur'an senantiasa mampu menjawab persoalan-persoalan zaman, bahkan pancasila dan al-Qur'an mampu membentuk masyarakat yang berperadaban.

\section{Kesimpulan}

Pemahaman kelisanan al-Qur'an dan Pancasila akan mengantarkan keduanya menjadi pedoman hidup umat Islam di Indonesia yang menjaga Indonesia dan apa yang ada di dalamnya. Al-Qur'an jika dipahami berdasarkan karakter kelisanannya, akan membawa pada kesadaran pentingnya pemahaman konteks Arab, sehingga akhirnya akan membedakan mana al-Qur'an sebaga pesan ilahi, teks al-Qur'an 
yang berbahasa Arab, dan konteks Nabi muhammad dan Masyarakat Arab ketika al-Qur'an itu disampaikan. Dari sini, terlihat upaya pengkontekstualisasian ajaran agama ke konteks Indonesia.

Kehadiran Pancasila dan kontekstualisasi al-Qur'an merupakan upaya dalam menjaga dan mengembangkan identitas Islam Indonesia. Hal ini terlihat dari nilainilai Pancasila yang berkaitan dengan nilai-nilai al-Qur'an. Bahkan kedua pedoman hidup tersebut mempertahankan jati diri Indonesia yang telah ada dan memajukan kehidupan berbangsa dan bernegara. Selain itu, melalui proses integrasi tersebut akan menciptakan kehidupan bernegara yang religius sekaligus sekuler, yakni negara yang berbasis agama dan berbasis ilmu pengetahuan sekaligus.

Jati diri Indonesia telah ada sebelum ajaran Islam sampai di bumi Indonesia, jati diri Indonesia telah ada sebelum pancasila lahir. Sehingga kehadiran Islam dan Pancasila tidak boleh mengubah Indonesia itu sendiri, tetapi mesti berdialog: budaya yang baik diambil, yang buruk dihilangkan. Melalui pemahaman atas kontekstualisasi ajaran Islam, maka Indonesia berkembang tanpa kehilangan jati dirinya. Melalui Pancasila, maka Indonesia kokoh dengan merangkul seisi Indonesia. Selanjutnya, kelisanan al-Qur'an yang tergambar dalam bentuk pancasila terus menjadi pedoman hidup bangsa Indonesia, yang senantiasa merespons perkembangan zaman, dan bahkan menjadi pencipta peradaban di Indonesia. Hal ini tentu dilakukan dengan integrasi ilmu umum (sains) yang merupakan basis pengembangan jati dri manusia.

\section{DAFTAR PUSTAKA}

Abbas, Abdullah bin. 2004. Tafsir Ibn Abbas. Beirut: Dar al-Kutub Al-ilmiyah.

Al-Husaini, Al-Hamid. 2000. Membangun Peradaban: Sejarah Muhammad Saw Sejak Sebelum Diutus Menjadi Rasul. Bandung: Pustaka Hidayah.

Al-Qaththan, Manna. 2005. Pengantar Studi Ilmu Al-Qur'an. Terj. Anunur Rafiq El-Mazni. Jakarta: Pustaka Al-Kautsa.

Arkoun, Muhammad. 1998. Kajian Kontemporer Al-Qur'an, Terj. Hidayatullah. Bandung: Pustaka.

As-Shali, Subhi. 1993. Membahas Ilmu-Ilmu Al-Qur'an.Jakarta: Pustaka Firdaus. Asy-Syafi'i, Imam. 1992. Ar-Risalah, Terj. Ahmadie Thoha. Jakarta: Pustaka Firdaus. 
Asy-Syuthi, Jalaluddin. 2008. Sebab Turunnya Ayat Al-Qur'an, Terj. Tim Abdul Hayyie. Jakarta: Gema Insani.

Bagir, Haidar. 2017. Islam Tuhan, Islam Manusia: Agama Dan Spiritualitas Di Zaman Kacau. Bandung: Mizan.

Baidan, Nashruddin. 1999. Tafsir Bi Al-Ra'yi: Upaya Penggalian Konsep Wanita Dalam Al-Qur'an, Mencermati Konsep Kesejajaran Wanita Dalam AlQur'an. Yogyakarta: Pustaka Pelajar.

Baqi, Muhammad Fuad Abdul. 1984. Mu’jam Al-Mufahras Li Al-Fazhi AlQur'an Al-Karim. Jilid I. Beirut: Dar al-Hadits.

Great Clarendon Street. 2019. Oxford Dictionary of English. New York: Oxford University Press. www.mobisystems.com.

Haleem, Muhammad Abdel. 2001. Understanding the Qur'an: Themes and Style. New York: I.B. Tauris dan Co Ltd.

- _ 2004. The Qur'an. New York: Oxford University Press Inc.

Hanafi, Hasan. 2003. Dari Akidah Ke Revolusi: Sikap Kita Terhadap Tradisi Lama, Terj. Asep Usman Ismail, Dkk. Jakarta: Paramadina.

Hariyono. 2014. Ideologi Pancasila: Roh Progresif Nasionalisme Indonesia. Malang: Intrans Publishing.

Hatta, Muhammad. 1977. Pengertian Pancasila. Jakarta: Idayu Press.

Hidayat, Asep Ahmad. 2009. Filsafat Bahasa: Mengungkap Hakikat Bahasa, Makna, Dan Tanda. Bandung: Remaja Rosdakarya.

Hidayat, Kamaruddin. 2004. Menafsirkan Kehendak Tuhan. Jakarta: Teraju.

Hitti, Philip K. 2006. History of The Arabs: From the Earliest Timer to the Present, Terj. R. Cecep Lukman Yasin Dan Dedi Slamet Riyadi. Jakarta: Serambi Ilmu Semesta.

HS, Muh. Alwi. 2019. "Perbandingan Tafsir Tulis Dan Lisan M. Quraish Shihab Tentang QS. Al-Qalam Dalam Tafsir Al-Misbah (Analisis Ciri Kelisanan Aditif Alih-Alih Subordinatif).” Jurnal Ilmiah Ushuluddin 18 No. 1(Januari-Juni).

Ismail, Faisal. 2016. Paradigma Kebudayaan Islam: Studi Kritis Analisis Historis. Yogyakarta: Penerbit Ombak.

Izutsu, Toshihiko. 1997. Relasi Tuhan Dan Manusia Pendekatan Semantik Terhadap Al-Qur'an, Terj. Yogyakarta: Tiara Wacana Yogya.

Khaldun, Ibnu. 2000. Muqaddimah Ibn Khaldun, Terj. Ahmadie Thoha. Jakarta: Pustaka Firdaus. 
Mandzur, Ibnu. Lisan Arab. Beirut: Dar Shadir.

Mattson, Ingrid. 2013. Ulumul Qur'an Zaman Kita: Pengantar Untuk Memahami Konteks, Kisah, Dasn Sejarah Al-Qur'an, Terj. R. Cecep Lukman Yasin. Jakarta: Zaman.

Misrawi, Zuhairi. 2017. Al-Qur'an Kitab Toleransi: Tafsir Tematik Islam Rahmatan Lil 'Alamin. Jakarta: Pustaka Oasis.

Ong, Walter J. 2013. Kelisanan Dan Keaksaraan. Terj. Rika Iffati. Yogyakarta: Penerbit Gading.

Qadafy, Mu’ammar Zayn. 2015. Buku Pintar Sababun Nuzul: Dari Mikro Hingga Makro. Yogyakarta: IN AzNa Books.

Rahman, Fazlur. 2017. Islam: Sejarah Pemikiran Dan Peradaban, Terj. M. Irsyad Rafsadie. Bandung: Mizan.

Saeed, Abdullah. 2016. Al-Qur'an Abad 21: Tafsir Kontekstual, Terj. Ervan Nurtawab. Bandung: Mizan.

Sahal, Akhmad, and Munawir Aziz. 2016. Islam Nusantara: Dari Ushul Fiqh Hingga Paham Kebangsaan. Cet. III. Bandung: Mizan.

Salim, Peter. Kamus Besar Indonesia Kontemporer. Jakarta: Modern English Press.

Samsuri. 1982. Analisis Bahasa: Mehamami Bahasa Secara Ilmiah. Jakarta: Erlangga.

Sardar, Zauddin. 2011. Reading the Qur'an the Contemporary Relevance of the Sacred Text of Islam. New York: Oxford University Press.

Saussure, Ferdinand de. 1988. Pengantar Lingiustik Umum, Terj. Rahayu S. Hidayat. Yogyakarta: Gadjah Mada University press.

Schoeler, Gregor. 2006. The Oral and The Writtern in Early Islam, Terj. Uwe Vagelpohl. New York: Routledge.

Shihab, M. Quraish. 1994. Studi Kritis Tafsir Al-Manar: Karya Muhammad Abduh Dan M. Rasyid Ridha. Jakarta: Pustaka Hidaya.

___ 2013. Kaidah Tafsir: Syarat, Ketentuan, Dan Aturan Yang Patut Anda Ketahui Dalam Memahami Al-Qur'an. Tangerang: Lentera Hati.

Sugiyono, Sugeng. 2009. Lisan Dan Kalam: Kajian Semantik Al-Qur'an. Yogyakarta: Sunan Kalijaga Press.

Sultan, Munir. 1986. I'jazul Qur'an Bain Al-Mu'tazilah Wa Al-Asy-Ariyah. Iskandariyah: Mansya'atul Ma'arif.

Ullmann, Stephen. 2012. Pengantar Semantik. Yogyakarta: Pustaka Pelajar. 
Umar, Nazaruddin. 2008. Ulumul Qur'an: Mengungkap Makna-Makna Tersembunyi Al-Qur'an. Jakarta: al-Ghazali Center.

Vansina, Jan. 2014. Tradisi Lisan Sebagai Sejarah. Terj. Astrid Reza, Dkk. Yogyakarta: Ombak.

Wahid, Abdurrahman. 2007. Islam Kosmopolitan: Nilai-Nilai Indonesia Dan Transformasi Kebudayaan. Jakarta: The Wahid institute.

Wahyudi, Yudian. 2009. Hermeneutika Sebagai Pengganti Ushul Fiqh? Yogyakarta: Pesantren Nawesea Press.

Wijaya, Aksin. 2009. Teori Interpretasi Al-Qur'an Ibnu Rusyd: Kritik IdeologiHermeneutis. Yogyakarta: LKiS.

Zaid, Nashr Hamid Abu. 2002. Tekstualitas Al-Qur'an: Kritik Terhadap Ulumul Qư'an, Terj. Khoiron Nahdliyyin. Yogyakarta: LKiS.

Zaid, Nasr Hamid Abu. 2003. Teks Otoritas Kebenaran, Terj. Sunarwoto Dema. Yogyakarta: LKis Yogyakarta.

Zakariya, Abu Al-Husain Ahmad bin Faris bin. 1979. Mu’jam Muqays Lugah. Jilid I. Beirut: Dar alFikr. 